\title{
Immunotherapy: incorporation in the evolving paradigm of renal cancer management and future prospects
}

\author{
Kenneth G. Liu ${ }^{1}$, Sorab Gupta ${ }^{2}$ and Sanjay Goel ${ }^{1}$ \\ ${ }^{1}$ Department of Medical Oncology, Montefiore Medical Center, Bronx, NY, USA \\ 2 Department of Internal Medicine, St. Barnabas Hospital, Bronx, NY, USA \\ Correspondence to: Sanjay Goel, email: sgoel@montefiore.org \\ Keywords: renal cell carcinoma; immunotherapy; checkpoint Inhibition; cytokines; vaccines \\ Received: August 20,2016 Accepted: December 13,2016 Published: December 30, 2016
}

\section{ABSTRACT}

Significant progress has been made in the management of renal cell carcinoma (RCC) during the last few decades. In early stage, localized disease, surgical resection remains the modality of choice, with no therapeutic interventions as options for post-operative therapy other than simple observation and clinical surveillance. However, treatment options in the advanced or metastatic setting are increasing at a dizzying pace, initially with cytokine therapy, then with the increased availability of targeted therapy including novel small-molecule inhibitors of receptor tyrosine kinases and monoclonal antibodies targeting novel proteins, establishing them as the current standard of care. Even more recently, immunotherapy has seen tremendous development in the form of immune checkpoint inhibition and vaccines. Overall, these interventions have gradually changed the landscape of cancer management in general, and metastatic renal cell carcinoma $(\mathrm{mRCC})$ in particular. This is exemplified by the recent United States Food and Drug Administration (USFDA) approval of nivolumab for patients with mRCC after failure of TKI therapy. In this review, we present a brief overview of the current management of $\mathrm{mRCC}$, primarily the clear cell subtype (cCRCC), and discuss the major clinical trials and data on the immunotherapy in advanced or $\mathrm{mRCC}$.

\section{INTRODUCTION}

For decades, therapeutic modalities for cancer management have primarily consisted of surgery, radiotherapy and chemotherapy. In renal cell carcinoma (RCC), surgical resection, either via nephron-sparing or radical nephrectomy, can be curative in patients with early stage, localized disease. However, no adjuvant treatment has been proven to be beneficial. A significant proportion of patients eventually develop tumor recurrence, and subsequent therapeutic options in the advanced or metastatic setting are limited. Since the turn of the millennium, novel small-molecule targeted therapy has evolved to become the mainstay of treatment for metastatic renal cell carcinoma (mRCC), though prognosis remains poor [1]. The past decade has seen the emergence of immunotherapy as an exciting treatment option for various malignancies, including RCC. The most common forms of immunotherapy include cytokine therapy and immune checkpoint inhibition, although vaccines are also being investigated. Cytokine therapy such as IL-2 and IFN- $\alpha$ was commonly used in the 1990's for mRCC, though its use has declined given modest response rates and poor tolerability. On the other hand, immune checkpoint inhibition has made significant progress and gained much attention with the approval for use in various solid tumors such as melanoma, non-small cell lung cancer and more recently, RCC $[1,2]$. In this review, we present a brief overview of the current management of $\mathrm{mRCC}$, primarily the clear cell subtype (ccRCC), and discuss the major clinical trials and data on the immunotherapy in advanced or mRCC.

\section{EPIDEMIOLOGY}

RCC represents $2-3 \%$ of all cancers, with the West contributing its major share to the associated morbidity and mortality. Worldwide, 209,000 new cases and 102,000 deaths per year are attributed to RCC [3]. RCC comprises $90 \%$ of all primary renal neoplasms and is a heterogeneous disease that progresses along varied pathophysiological 
pathways. The most common subtypes are clear cell, papillary and chromophobe, while there are at least ten other rarer subtypes based on recent re-classification by the International Society of Urologic Pathology [4]. $\mathrm{RCC}$ is known to occur predominantly in the sixth and seventh decades of life [3]. Young adults less than 40 years of age and children are rarely affected, though they are more likely to have symptomatic tumors $[5,6]$. It is also known to have a male predilection as compared to females (2:1), making it the seventh most common cancer in men while being the ninth most common cancer in women [3]. The incidence of RCC differs among various ethnic populations. In the United States, incidence rates are lowest among Asian and Pacific Islanders, while being much higher among Whites and Blacks, suggesting a potential role for both genetic and environmental factors [7]. The risk of developing RCC may be increased by lifestyle-modifying factors such as smoking (both active and passive), obesity and hypertension. It is also more common in patients with end-stage renal disease, acquired renal cystic disease, and tuberous sclerosis. In addition, environmental exposures to asbestos, cadmium, dry-cleaning solvents, gasoline and other petroleum by-products, as well as prolonged use of non-aspirin NSAIDs may increase the risk of developing RCC [8, 9]. Approximately $2-3 \%$ of RCC are familial, with von Hippel-Lindau syndrome being the most common [3].

\section{PROGNOSIS}

Most RCCs are clinically silent during their course and therefore a diagnosis may not be made until they become locally advanced or metastatic. However, in more recent years, a significant proportion of RCCs are also detected incidentally. The difference in prognosis between early and advanced stage disease is striking. In the United States, the 5-year survival (from 20052011) was $92 \%$ for localized disease, $65 \%$ for regional disease (spread to the lymph nodes), and only $12 \%$ for distant disease (metastases) [10]. These statistics not only highlight the importance of developing effective therapy in the metastatic setting, but also lead to the development of different prognostic models to help guide treatment in advanced RCC.

The UCLA Integrated Staging System (UISS) is a prognostic model that incorporates information obtained from anatomic stage (based on the 1997 tumor-nodemetastasis stage), Fuhrman's grade, and the Eastern Cooperative Oncology Group (ECOG) performance status. Based on these criteria, patients were divided into low, intermediate and high risk categories. This system was validated in a prospective cohort involving RCC patients who underwent nephrectomy $[11,12]$. For recurrent or mRCC, one of the most commonly used prognostication systems is the one proposed by the Memorial Sloan Kettering Cancer Center (MSKCC) group that integrates five adverse factors: low Karnofsky performance status score (less than 80), high serum lactate dehydrogenase level (LDH; greater than 1.5 times the upper limit of normal), low hemoglobin level (less than the lower limit of normal), high corrected calcium (greater than the upper limit of normal), and short interval from diagnosis to treatment (less than one year). In the original study, patients with mRCC received interferon- $\alpha$ as first-line therapy. Patients with none of the risk factors compared to those with one or two and those with three or more risk factors had significantly higher one-year $(83 \% v s$. $58 \%$ vs. $20 \%$ ) and three-year overall survival (OS) rates ( $45 \%$ vs. $17 \%$ vs. $2 \%$ ) [13]. In the era of targeted therapy, the International Metastatic RCC Database Consortium (IMDC) model has been proposed. The IMDC model is based on six adverse clinical factors, four of which are from the MSKCC model (Karnofsky performance status, diagnosis-to-treatment interval, hemoglobin, and corrected calcium). In addition, neutrophils and platelets greater than the upper limit of normal were identified as independent adverse prognostic factors. This model was validated in a large, multicenter study involving mRCC patients who received sunitinib, sorafenib and bevacizumab [14].

\section{CURRENT TARGETED THERAPY}

Currently, targeted therapy involving tyrosinekinase inhibitors (TKI), especially, the anti-vascular endothelial growth factor (VEGF) agents are widely used in the first and second line treatment for $\mathrm{mRCC}$. Prognostic risk stratification as described earlier is often helpful in the selection of the targeted therapy. As ccRCC represents the most common subtype of RCC, it has been the major focus of clinical trials. In the front-line setting, sunitinib, pazopanib and temsirolimus are the agents most routinely used based on data from a number of clinical trials. Sunitinib, a multikinase inhibitor, was compared against IFN- $\alpha$ in the first-line setting and was found to have improved progression-free survival (PFS) and OS. The vast majority of the patients in the trial were considered "favorable" or "intermediate" according to the MSKCC prognostic model, therefore, sunitinib is typically used in patients meeting such criteria [15, 16]. Pazopanib is another multikinase inhibitor that has shown efficacy in the first-line setting. Pazopanib was compared to placebo and was shown to have significantly prolonged PFS [17]. OS was similar, but could be explained by the extensive crossover of placebo patients onto the pazopanib arm [18]. Pazopanib was also directly compared with sunitinib, with pazopanib showing similar efficacy but appeared to be better tolerated than sunitinib $[19,20]$. Meanwhile, temsirolimus, an inhibitor of the mammalian target of rapamycin (mTOR) protein, has been investigated in "poor" risk patients. In a randomized phase III trial, temsirolimus was evaluated as monotherapy or in combination with IFN- $\alpha$. Temsirolimus was found 
to have improved PFS and OS compared to IFN- $\alpha$, while the combination did not yield additional benefit despite an increase in adverse events [21]. Based on these data, temsirolimus is now approved for first-line treatment of "poor" risk metastatic RCC. Other acceptable treatment options in the front-line setting include bevacizumab (an anti-VEGF monoclonal antibody) in combination with IFN- $\alpha$ [22, 23], sorafenib (a multikinase inhibitor) [24] and axitinib (a multikinase inhibitor that acts by inhibiting VEGF) [25].

For therapy in the second-line setting and beyond, the choice of targeted agent is typically tailored based on what the patient receive in the first-line setting. Cabozantinib, another multikinase inhibitor, was studied with everolimus as the control, in patients who had been treated with prior TKI therapy, and was shown to have improved PFS and OS [26, 27]. Axitinib can be used in patients who received one prior systemic therapy based on a randomized trial where it was compared with sorafenib and was shown to have improved PFS but not OS [28, 29]. Meanwhile, lenvatinib alone and in combination with everolimus were found to prolong PFS when compared to everolimus alone for patients who have received one prior anti-angiogenic therapy, with the combination recently being approved by the United States Food and Drug Administration (USFDA) [30]. Finally, everolimus alone [31], sorafenib [32] and pazopanib [17] have all been investigated in the second-line setting when compared to placebo and demonstrated improved PFS. Other agents that are available include sunitinib, temsirolimus and bevacizumab.

In summary, we believe that the management of mRCC has turned into an "embarrassment of riches" with a multitude of options, and it is almost impossible that a patient will be able to avail of all the options available. Our recommendation when dealing with a newly diagnosed $\mathrm{mRCC}$ patient is to first perform risk stratification and determine prognosis. For patients with good or intermediate risk and ccRCC, offer sunitinib or pazopanib as these appear to have the best data, and can be used as a single agent. For patients with poor risk or non clear cell RCC, offer temsirolimus as front line therapy. For patients who are intolerant to one of these agents, offer them an alternate therapy from among the front line agents listed above. For those patients who have progressed on front line therapy, the preferred options are nivolumab, cabozantinib, or the combination of lenvatinib and everolimus, as these three options have demonstrated a survival advantage.

\section{CYTOREDUCTIVE NEPHRECTOMY}

Prior to the widespread use of targeted therapy and immunotherapy, mRCC was associated with a dismal prognosis given the limited role of chemotherapy. Treatment was limited to cytokine therapy. Cytoreductive nephrectomy was proposed as a modality to improve outcomes. This was based on several reports in the literature suggesting spontaneous regression of metastases in patients who have undergone nephrectomy [33, 34]. While the exact mechanism is not entirely known, immunologic factors are felt to play important role [35]. Cytoreductive nephrectomy was subsequently investigated in two similar randomized phase III trials. In a study conducted by the Southwest Oncology Group (SWOG), patients were randomized to receive either radical nephrectomy followed by IFN- $\alpha-2 b$, or IFN- $\alpha-2 b$ therapy alone. OS was 11.1 months in the surgery arm compared with 8.1 months in the interferon-only $\operatorname{arm}(P=0.05)$ [36]. Meanwhile, the European Organisation for Research and Treatment of Cancer (EORTC) similarly compared radical nephrectomy followed by IFN- $\alpha$ versus IFN- $\alpha$ alone. OS was significantly improved (17 months vs. 7 months) favoring the surgery arm [37]. However, cytoreductive nephrectomy is not without its morbidity, and careful selection of patients should be undertaken. A retrospective analysis identified 7 independent preoperative predictors of inferior OS in surgical patients: a LDH level greater than the upper limit of normal, an albumin level less than the lower limit of normal, symptoms at presentation caused by a metastatic site, liver metastasis, retroperitoneal adenopathy, supradiaphragmatic adenopathy, and clinical tumor classification $\geq T 3$. Patients with $\geq 4$ risk factors did not appear to benefit from surgery [38]. Finally, the role of cytoreductive nephrectomy is not entirely clear in patients who will undergo targeted therapy. A study published by the International Metastatic RCC Database Consortium demonstrated improved OS for patients who underwent cytoreductive nephrectomy who are subsequently treated with VEGF-targeted agents, although the benefit is marginal in those with poor risk features [39]. A randomized phase III trial (CARMENA) is currently underway to investigate the importance of cytoreductive nephrectomy in $\mathrm{mRCC}$ patients treated with sunitinib [NCT00930033] [40].

\section{IMMUNOTHERAPY}

Immunotherapy is often considered a new treatment modality in the management of cancer. However, its use was first reported back in the late 19th century, when surgeon William Coley demonstrated that the injection of killed bacterial products into inoperable sarcoma tissue led to the shrinkage of tumor [41]. He subsequently developed a mixed bacterial vaccine and was able to achieve longterm remissions in some patients with sarcoma and various tumor types [42, 43]. It was later recognized that cancer cells express tumor antigens that may stimulate cellular and/or humoral responses. Peptides derived from tumor antigens are presented via major histocompatibility complex (MHC) class I and class II epitopes and may stimulate $\mathrm{CD} 8+$ and $\mathrm{CD} 4+\mathrm{T}$ cells respectively [2]. 
The binding of the $\mathrm{T}$ cell receptor (TCR) to the peptide presented by $\mathrm{MHC}$ requires further co-stimulatory signals, and its interaction activates downstream pathways resulting in the secretion of proinflammatory cytokines [44]. However, the amplitude and quality of the response are regulated by a balance between co-stimulatory and inhibitory signals, known as immune checkpoints [45].

In mRCC, various forms of immunotherapy, including cytokines, immune checkpoint inhibitors, vaccines, have been used or tested. The following sections will discuss these in more detail.

\section{Cytokine therapy}

Prior to the development of targeted therapy, cytokines such as IL-2 and IFN- $\alpha$ were used for the management of mRCC. However, these are typically associated with significant toxicity with mild clinical benefit. High dose IL-2 was approved by the USFDA as early as 1992 for the treatment of mRCC based on data from phase II trials. Fyfe et al. reported data on 255 patients (from 7 different phase II trials) who received high dose IL-2. The objective response rate (ORR) was $14 \%$ ( $5 \%$ complete response and 9\% partial response). However, treatment was associated with significant toxicities, including grade 3 and 4 hypotension (74\%), nausea/vomiting $(25 \%)$, diarrhea $(22 \%)$, mental status changes $(28 \%)$, elevated bilirubin $(21 \%)$, oliguria/anuria (46\%), fever/chills (24\%), thrombocytopenia (21\%), though recovery was considered rapid [46]. A subsequent retrospective analysis reviewed data from $259 \mathrm{mRCC}$ patients treated with high dose IL-2 at the National Cancer Institute between 1986 and 2006, and confirmed a 20\% ORR. Of note, disease recurrence occurred in all patients with partial response (PR), while 19 of 23 patients $(83 \%)$ with complete response (CR) were disease-free at the time of last follow-up [47].

Further studies focused on determining whether lower doses of IL-2 could produce similar efficacy with lower toxicity. The Cytokine Working Group conducted a randomized phase III study which compared high dose IL-2 with the outpatient combination of IL- 2 and IFN- $\alpha$. The response rate was $23.2 \%$ in the high dose IL-2 group versus $9.9 \%$ in the outpatient combination group. No significant differences in PFS and OS were noted. However, significant difference in OS favoring high dose IL-2 were seen in patients with liver and bone metastases $(P=0.001)$ and in patients whose primary tumors were still in place $(P=0.040)$ [48]. The National Cancer Institute designed a phase III trial comparing high-dose IL-2 (720,000 U/kg every 8 hours) and low-dose IL-2 (72,000 U/kg every 8 hours). Toxicities were less frequent with low-dose IL-2, but there was a higher ORR with high-dose (21\%) compared with low-dose (13\%). No OS difference was noted [49]. Based on results from these studies, high-dose IL-2 can potentially achieve durable responses in carefully selected patients with mRCC. However, it has gradually fallen out of favor in the firstline setting in this current era of targeted therapy and immunotherapy.

\section{Checkpoint inhibition}

There are a number of mechanisms through which immune invasion by tumor cells can occur. These mechanisms include downmodulation of tumor antigen presentation by downregulation of MHC class I molecules, upregulation of inhibitors of apoptosis, or expression of cell surface molecules that directly kill cytotoxic $\mathrm{T}$ cells. Tumors may also release factors that induce inhibition of both the innate and the adaptive anti-tumor immunity, as well as recruit regulatory cells to generate an immunosuppressive microenvironment $[50,51]$. Finally, immune checkpoint proteins may become dysregulated, typically via overexpression of inhibitory ligands and receptors that regulate $\mathrm{T}$ cell effector functions in the tumor microenvironment [45].

The two immune checkpoint receptors most commonly targeted are the cytotoxic T-lymphocyteassociated antigen 4 (CTLA-4) and programmed cell death protein 1 (PD-1). CTLA-4 is present on the surface of T cells and counteracts the action of co-stimulatory receptor CD28. Both CTLA-4 and CD28 bind identical ligands CD80 and CD86, but CTLA-4 does so at a higher affinity, thus out competing CD28 and dampens the activation of T cells. In addition, CTLA-4 may directly sequester CD80 and CD86 from CD28 engagement, as well as active removal of CD80 and CD86 from the antigenpresenting cell surface $[45,52]$. CTLA-4 antibodies were initially tested on mouse models of colon adenocarcinoma and sarcoma and were noted to induce tumor shrinkage [53]. These encouraging results subsequently led to the development of two CTLA-4 antibodies, ipilimumab and tremelimumab.

PD-1 is a transmembrane protein that is more broadly expressed than CTLA-4. It is found in T cells, as well as B cells and natural killer cells. It binds to two ligands, PD-L1 and PD-L2, which are commonly expressed on the tumor cell surface of multiple tumor types. The interaction of PD-1 and its ligands inhibits kinases that are involved in $\mathrm{T}$ cell activation, induces anergy among antigen-specific $\mathrm{T}$ cells and converts effector $\mathrm{T}$ cells into regulatory $\mathrm{T}$ cells $[45,54]$. Blockade of this interaction was subsequently evaluated and the initial clinical trial demonstrated impressive tumor regression in various refractory tumor types, including $\mathrm{RCC}$, melanoma, non-small cell lung cancer and colorectal cancer [55].

Immune checkpoint inhibition has quickly become a major focus of research over the past decade given its durable response rates and promising survival benefits in various malignancies. A number of inhibitors in the PD-1 
Table 1: Current ongoing clinical trials involving checkpoint inhibitors in mRCC

\begin{tabular}{|c|c|c|c|c|c|}
\hline Primary Drug & Phase & Line & Malignancy & Arms & NCT number \\
\hline Nivolumab & IV & $2^{\text {nd }}$ & RCC & Nivolumab & NCT02596035 \\
\hline Atezolizumab & III & $1^{\text {st }}$ & $\mathrm{RCC}$ & $\begin{array}{l}\text { Atezolizumab + Bevacizumab } \\
\text { Sunitinib }\end{array}$ & NCT02420821 \\
\hline Avelumab & III & $1^{\text {st }}$ & $\mathrm{RCC}$ & $\begin{array}{l}\text { Avelumab + Axitinib } \\
\text { Sunitinib }\end{array}$ & NCT02684006 \\
\hline $\begin{array}{ll}\text { Nivolumab } & + \\
\text { Ipilimumab } & \\
\end{array}$ & III & $1^{\text {st }}$ & $\mathrm{RCC}$ & $\begin{array}{l}\text { Nivolumab + Ipilimumab } \\
\text { Sunitinib }\end{array}$ & NCT02231749 \\
\hline Atezolizumab & II & $1^{\text {st }}$ & $\mathrm{RCC}$ & $\begin{array}{l}\text { Atezolizumab } \\
\text { Atezolizumab }+ \text { Bevacizumab } \\
\text { Sunitinib }\end{array}$ & NCT01984242 \\
\hline Ipilumumab & II & $1^{\text {st }} / 2^{\text {nd }}$ & $\mathrm{RCC}$ & Ipilimumab & NCT00057889 \\
\hline Nivolumab & II & $1^{\text {st }}$ & $\mathrm{RCC}$ & Nivolumab (pre- and post-op) & NCT02446860 \\
\hline Atezolizumab & $\mathrm{I} / \mathrm{II}$ & $2^{\text {nd }}$ & Solid tumors & Atezolizumab + Varlilumab & NCT02543645 \\
\hline Pembrolizumab & $\mathrm{I} / \mathrm{II}$ & $1^{\text {st }}$ & $\mathrm{RCC}$ & $\begin{array}{l}\text { Pembrolizumab } \\
\text { Pazopanib } \\
\text { Pembrolizumab + Pazopanib }\end{array}$ & NCT02014636 \\
\hline Pembrolizumab & $\mathrm{I} / \mathrm{II}$ & $1^{\mathrm{st}} / 2^{\text {nd }}$ & $\mathrm{RCC}$ & Pembrolizumab + Bevacizumab & NCT02348008 \\
\hline Pembrolizumab & $\mathrm{I} / \mathrm{II}$ & $1^{\text {st } / 2^{\text {nd }}}$ & RCC & Pembrolizumab + Vorinostat & NCT02619253 \\
\hline Pembrolizumab & $\mathrm{I} / \mathrm{II}$ & $2^{\text {nd }}$ & Solid tumors & Pembrolizumab + Lenvatinib & NCT02501096 \\
\hline Pembrolizumab & $\mathrm{I} / \mathrm{II}$ & $2^{\text {nd }}$ & Solid tumors & Pembrolizumab + Epacadostat & NCT02178722 \\
\hline Nivolumab & $\mathrm{I} / \mathrm{II}$ & $2^{\text {nd }}$ & Solid tumors & Nivolumab + Varlilumab & NCT02335918 \\
\hline Atezolizumab & I & $2^{\text {nd }}$ & Solid tumors & $\begin{array}{l}\text { Atezolizumab + CPI-444 } \\
\text { CPI-444 }\end{array}$ & NCT02655822 \\
\hline Avelumab & I & $1^{\text {st }}$ & RCC & Avelumab + Axitinib & NCT02493751 \\
\hline $\begin{array}{l}\text { Durvalumab }+ \\
\text { AMP-514 }\end{array}$ & I & $2^{\text {nd }}$ & Solid tumors & Durvalumab + AMP-514 & NCT02118337 \\
\hline $\begin{array}{l}\text { Durvalumab } \\
\text { Tremelimumab }\end{array}$ & I & $2^{\text {nd }}$ & Solid tumors & Durvalumab + Tremelimumab & NCT01975831 \\
\hline Ipilimumab & $\mathrm{I}$ & $2^{\text {nd }}$ & Solid tumors & Ipilimumab + MGA271 & NCT02381314 \\
\hline Pembrolizumab & I & $1^{\text {st }}$ & RCC & Pembrolizumab + Axitinib & NCT02133742 \\
\hline Pembrolizumab & $\mathrm{I}$ & $2^{\text {nd }}$ & Solid tumors & Pembrolizumab + Ziv-Afilbercept & NCT02298959 \\
\hline Pembrolizumab & $\mathrm{I}$ & $2^{\text {nd }}$ & Solid tumors & $\begin{array}{l}\text { Pembrolizumab + INCB039110 } \\
\text { Pembrolizumab + INCB050465 }\end{array}$ & NCT02646748 \\
\hline Pembrolizumab & $\mathrm{I}$ & $2^{\text {nd }}$ & Solid tumors & Pembrolizumab + MGA271 & NCT02475213 \\
\hline $\begin{array}{l}\text { Pembrolizumab }+ \\
\text { Ipilimumab }\end{array}$ & I & $2^{\text {nd }}$ & $\begin{array}{l}\mathrm{RCC}, \\
\text { melanoma }\end{array}$ & $\begin{array}{l}\text { Pembrolizumab } \\
\text { Pembrolizumab + Ipilimumab } \\
\text { Pembrolizumab + PEG IFN- } \alpha-2 b\end{array}$ & NCT02089685 \\
\hline Nivolumab & I & $1^{\mathrm{st}} / 2^{\mathrm{nd}}$ & $\mathrm{RCC}$ & $\begin{array}{l}\text { Nivolumab + Sunitinib } \\
\text { Nivolumab + Pazopanib } \\
\text { Nivolumab + Ipilimumab }\end{array}$ & NCT01472081 \\
\hline Nivolumab & I & $2^{\text {nd }}$ & Solid tumors & Nivolumab + IFN- $\gamma$ & NCT02614456 \\
\hline Nivolumab & $\mathrm{N} / \mathrm{A}$ & $1^{\mathrm{st} / 2^{\text {nd }}}$ & $\mathrm{RCC}$ & $\begin{array}{l}\text { Nivolumab } \\
\text { Nivolumab + Bevacizumab } \\
\text { Nivolumab + Ipilimumab }\end{array}$ & NCT02210117 \\
\hline
\end{tabular}

(Varlilumab = an anti-CD27 monoclonal antibody; Vorinostat $=$ a histone deacetylase inhibitor; Epacadostat $=$ an indoleamine 2,3-dioxygenase inhibitor; CPI-444 = an antagonist of the adenosine-A2A receptor; AMP-514 = an anti-PD-1 monoclonal antibody; MGA271 = an anti-B7-H3 monoclonal antibody; ICNB039110 = a JAK inhibitor with JAK1 selectivity; ICNB050465 = a PI3K-delta inhibitor)

pathway are currently being developed actively in clinical trials. These include nivolumab and pembrolizumab, which are PD-1 inhibitors, as well as atezolizumab, durvalumab and avelumab, which are PD-L1 inhibitors [56]. There are also anti-CTLA-4 antibodies that have been developed, including ipilimumab and tremelimumab [57]. Currently, multiple clinical trials studying the efficacy of these agents on $\mathrm{mRCC}$ are being conducted, with nivolumab being the only agent that is approved by the USFDA for the treatment of RCC [58]. 
In addition, there are multiple ongoing trials investigating whether immunotherapy combinations, with each other or with targeted therapy, can yield additional benefit in $\mathrm{mRCC}$. Chen and Mellman proposed a cancerimmunity cycle in which a series of stepwise events are needed in order for an anticancer immune response to lead to effective killing of cancer cells. Combining agents that target different parts of the cycle may lead to synergistic effects. For example, anti-CTLA-4 antibodies enhance priming and activation of antigen-specific $\mathrm{T}$ cells, while the blockade of the PD-1 pathway removes the inhibition of cancer cell killing by T cells [59]. This combination appears to provide clinical activity distinct from monotherapy alone in metastatic melanoma [60]. In addition, immunotherapy in combination with agents that enhance $\mathrm{T}$ cell trafficking and infiltration into the tumor bed, such as VEGF inhibitors, may also potentially provide additional clinical benefit not seen with either modality alone (Figure 1) [61-63].

Checkpoint inhibitors have their limitations in that a large proportion of patients do not respond to the treatments. In general, tumors with a higher mutational burden are associated with better response and durable clinical benefit [64]. The expression of PD-L1 also appears to correlate with elevated tumor-infiltrating lymphocytes and is associated with response to monoclonal antibodies targeting the PD-1/PD-L1 pathway [65]. Based on these principles, recent research have shown that increasing effector T cells tumor infiltration may improve the efficacy of PD-L1 checkpoint blockade [66].

As a class, checkpoint inhibitors are associated with a range of immune-related adverse events. The most common and typically earliest onset adverse reaction is dermatologic toxicity, which is usually managed by topical corticosteroid cream. Diarrhea/colitis is also common, but has a much higher incidence with CTLA-4 antibodies than antibodies targeting PD-1/PD-L1. Hepatotoxicity and endocrinopathy in the form of hypophysitis and hypothyroidism are also occasionally encountered. Other organs that may potentially be affected include lung, eye, kidney, pancreas, as well as neurologic or hematologic syndromes [67].

The following section describes the various checkpoint inhibitors that are being investigated in the management of mRCC (Table 1).

\section{Immunologic}

\section{Empiric}

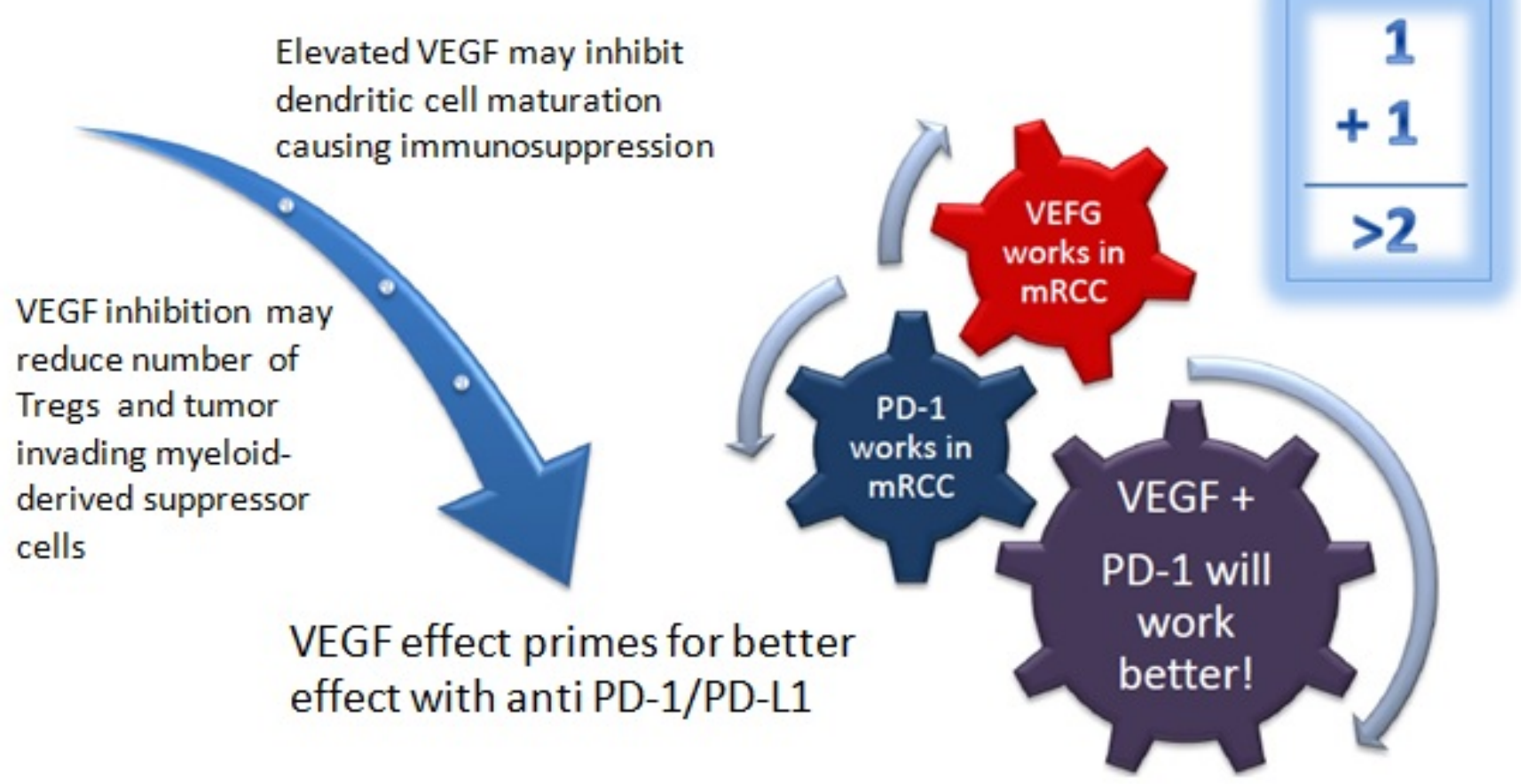

Figure 1: Schematic of the possible mechanism behind the synergy of anti-VEGF TKI's and anti PD-1/PD-L1 antibodies. (Figure used with permission from Dr. Elizabeth Plimack, Fox Chase Cancer Center) 


\section{Nivolumab}

Nivolumab (Opdivo ${ }^{\circledR}$, Bristol-Myers Squibb, Princeton, NJ) is a fully human IgG4 anti-PD-1 immune checkpoint inhibitor monoclonal antibody. It has been studied extensively in various cancers, and has received approval by the USFDA for the treatment of $\mathrm{mRCC}$, in addition to metastatic melanoma and squamous and nonsquamous non-small cell lung cancer, and more recently, in Hodgkin Disease [68, 69].

Its initial development in renal cancer was as a phase II trial involving previously treated metastatic ccRCC patients. Nivolumab was dosed at $0.3,2$ and $10 \mathrm{mg} / \mathrm{kg}$ every 3 weeks, and was noted to produce ORR in $20-22 \%$ of patients with an OS of 18.2-25.5 months [70]. Given the promising data in this phase II study, a randomized, openlabel, phase III study was developed comparing nivolumab to everolimus in patients who received prior treatment (Check Mate 025). 821 patients were randomly assigned $1: 1$ to receive either nivolumab $3 \mathrm{mg} / \mathrm{kg}$ intravenously every 2 weeks or everolimus $10 \mathrm{mg}$ orally every day. The median OS were 25.0 months (95\% confidence interval (CI), 21.8-not estimable) in the nivolumab group and 19.6 months (95\% CI, 17.6-23.1), with the hazard ratio $(\mathrm{HR})$ for death of $0.73(98.5 \% \mathrm{CI}, 0.57-0.93 ; P=0.002)$ favoring the nivolumab group. The objective response rates also favored the nivolumab group $(25 \%$ vs. $5 \% ; P<$ 0.001 ), though the median PFS were similar (4.6 months vs. 4.4 months; HR $0.88 ; P=0.11)$. The authors postulated that there might be a potential delayed benefit in PFS with nivolumab based on the late separation of the PFS curves and that PFS was not a surrogate for OS in this study. A benefit was observed with nivolumab irrespective of PDL1 expression. Grade 3 or 4 treatment-related adverse events were less in the nivolumab group (19\%) compared with the everolimus group (37\%). Given improvement in efficacy and fewer treatment-related side effects compared to everolimus, nivolumab was established as a new standard of care in the management of advanced clear cell RCC in the second-line setting [58]. Nivolumab is under investigation as pre- and post-operative therapy in metastatic RCC (ADAPTeR) [NCT02446860] [71] and is also being studied in combination with other drugs [NCT01472081, NCT02231749, NCT02210117, NCT02335918, NCT02614456] [72-76].

\section{Pembrolizumab}

Pembrolizumab (Keytruda ${ }^{\circledR}$, Merck, Whitehouse Station, NJ) is a highly selective humanized IgG4 antibody that targets the PD-1 receptor and USFDA approved metastatic melanoma, squamous and nonsquamous non-small cell lung cancer, and head and neck cancer [81]. It is currently being investigated for use in mRCC. Preliminary safety data from a recent phase I/
II study (KEYNOTE-029) involving pembrolizumab plus ipilimumab or pegylated interferon alfa-2b (PEGIFN) in patients with metastatic melanoma and RCC was recently reported [82]. There are also multiple ongoing studies evaluating pembrolizumab in combination with various drugs with different mechanisms [NCT02014636, NCT02133742, NCT02348008, NCT02089685, NCT02501096, NCT02619253, NCT02298959, NCT02646748, NCT02178722, NCT02475213] [83-92].

\section{Atezolizumab}

Atezolizumab is a fully humanized monoclonal IgG1 antibody that targets PD-L1. It is being evaluated in multiple different cancers, including RCC. A recent phase Ia study involving atezolizumab in $\mathrm{mRCC}$ was recently reported. Of the 63 patients with clear cell RCC that were evaluable, median PFS was 5.6 months and median OS was 28.9 months. The objective response rate was $15 \%$ (18\% in patients with $>1 \%$, and $9 \%$ in those with $<1 \%$ PD-L1 expression) [93]. Several other trials involving atezolizumab are currently underway [NCT01984242, NCT02420821, NCT02543645, NCT02655822] [94-97].

\section{Avelumab}

Avelumab (MSB0010718C) is a fully human anti-PD-L1 IgG1 monoclonal antibody that works by inhibiting PD-1/PD-L1 interactions while leaving PD-1/ PD-L2 pathway intact. It may also induce antibodydependent cell-mediated cytotoxicity (ADCC) by retaining a native $\mathrm{Fc}$ region. In a phase Ib study, avelumab was used in patients with refractory solid tumors and showed similar toxicity profiles compared to other PD-1 or PDL1 inhibitors [98]. Two ongoing trials are evaluating avelumab in combination with axitinib [NCT02493751, NCT02684006] [99, 100].

\section{Durvalumab}

Durvalumab (MEDI4736) is another human antiPD-L1 IgG1 monoclonal antibody. It blocks PD-L1 binding to PD-1 and CD80, with no binding to PD-L2. ADCC and complement-dependent cytotoxicities are removed by an engineered triple mutation in the $\mathrm{Fc}$ domain. A Phase 1/2, multicenter, open-label study which evaluated the safety and clinical activity of the drug in patients with multiple solid tumor types such as non-small cell lung cancer noted very manageable safety profile [101]. There are ongoing trials evaluating durvalumab in combination with other drugs, including tremelimumab (a fully human monoclonal antibody against CTLA4) $[\mathrm{NCT} 01975831]$ [102] and MEDI0680 (AMP-514) (a humanized $\mathrm{IgG} 4$ monoclonal antibody against PD- 
1) [NCT02118337] [103] for patients with advanced malignancies including RCC.

\section{Ipilimumab}

Ipilimumab $\left(\right.$ Yervoy $^{\circledR}$, Bristol-Myers Squibb, Princeton, NJ) is an anti-CTLA-4 IgG1 monoclonal antibody that is USFDA approved in melanoma [104]. It has been investigated as a single agent and in combination with nivolumab in metastatic melanoma, with the combination shown to be more effective albeit with significantly more toxicity [77]. This combination of nivolumab and ipilimumab is currently being investigated in mRCC. In a phase I study, patients were randomized into 2 groups with different dosing combinations followed by maintenance nivolumab until disease progression or unacceptable toxicity. Objective responses were noted in 15 of 44 patients $(34 \%)$ and stable disease was seen in another 16 patients (36\%) [78]. Further trials investigating ipilimumab alone [NCT00057889] [79] and in combination with other drugs are ongoing [NCT02231749, NCT02381314] [73, 80].

\section{Tremelimumab}

Tremelimumab is another anti-CTLA-4 antibody that is actively being investigated in mRCC. Unlike ipilimumab, it is an IgG2 antibody. As discussed previously, it is currently being evaluated with durvalumab in the treatment of patients with mRCC [NCT01975831] [102].

\section{Vaccines}

Vaccines are also under active investigation in RCC. They are aimed at treatment of the primary tumor rather than prevention, and uses the patient's tumor cells or tumor-associated products for immune recognition. Clinical trials evaluating various vaccines have been conducted, although none has demonstrated an improvement in survival thus far. AGS-003 is a dendritic cell (DC) based vaccine in which mature DCs are co-electroporated with amplified tumor mRNA and synthetic CD40L RNA. CD40L expression on the DC surface is thought to cause T-cell activation by inducing co-stimulatory signals. A phase II study on 21 intermediate or poor-risk mRCC patients eligible for nephrectomy were treated by a combination therapy of AGS-003 with sunitinib. Median PFS and OS were 11.2 and 30.2 months respectively [105]. Based on these results, a phase III ADAPT study is currently underway, in which mRCC patients undergoing debulking nephrectomy are randomly assigned to sunitinib alone or sunitinib plus AGS-003 [NCT01582672] [106].
IMA-901 is a vaccine developed from multiple tumor-associated peptides (TUMAP) that are naturally presented in human cancer tissue. In a phase II trial utilizing the co-administration of cyclophosphamide (which reduces the inhibitory regulatory T cells), IMA-901 demonstrated a disease control rate of $31 \%$ at 6 months in patients previously treated with cytokine therapy, and 14\% at 6 months in patients previously treated with tyrosine kinase inhibitors [107]. In a separate phase III trial, 339 patients were randomly assigned to receive sunitinib or to sunitinib plus IMA901 and GM-CSF. OS was not improved with the addition of the IMA901 vaccine compared with sunitinib alone [108].

TroVax (MVA-5T4) is a therapeutic vaccine targeting a glycosylated 5T4 antigen expressed on human placental trophoblasts and various human cancer cells. This particular tumor-associated antigen is overexpressed in most RCCs [109]. In a phase III TRIST trial, MVA-5T4 in combination with IFN- $\alpha$, IL-2 or sunitinib as first-line mRCC therapy did not result in a significant increase in OS when compared to the arm without MVA-5T4 [110].

There are other ongoing trials involving DC-based vaccines. Some of the promising ones involve transduction of a fusion gene construct of GM-CSF and carbonic anhydrase IX into autologous DCs [NCT01826877] [111], pidilizumab (a PD-1 antibody) in combination with DC/RCC fusion cells [NCT01441765] [112], and DCs in combination with cytokine-induced killer cells [NCT00862303] [113].

\section{Adjuvant immunotherapy}

Given the success and promising data involving checkpoint inhibition in metastatic RCC, it is reasonable to ask the question whether immunotherapy plays a role in the non-metastatic adjuvant setting. However, various randomized trials of adjuvant therapy involving tumor cells plus BCG, tumor cell vaccination, IFN- $\alpha$, high-dose IL-2, or a combination of cytokines have not demonstrated survival benefit when compared with observation [114]. The role of checkpoint inhibition has not been investigated in the adjuvant setting. Therefore, at this time, observation is still the recommended approach in stage I-III RCC following nephrectomy.

\section{Immunotherapy in combination with radiotherapy}

$\mathrm{RCC}$ is often considered to be a radio-resistant disease and the role of radiation is generally limited to palliative or local control. Preclinical data from the 1990's from a RCC mouse model demonstrated the regression of lung metastases with radiation and an even greater degree of decrease when combined with IL-2 [115]. In addition, over the past decade, there is growing 
evidence that stereotactic radiotherapy may overcome resistance, although currently no randomized clinical trials have been done. Although the exact mechanism is not known, one hypothesis is that when radiotherapy is applied in a high-dose, few-fraction schedule, dendritic cells are recruited to the irradiated site, which adopt the tumor antigens and presented to cytotoxic T lymphocytes in the lymph nodes [116]. Currently, there is an ongoing clinical trial evaluating radiation therapy in combination with pembrolizumab for patients with recurrent or mRCC [NCT02318771] [117].

\section{CONCLUSION}

The role of immunotherapy in the management of RCC has changed dramatically since the turn of the century. Previously, cytokine therapy involving IL-2 and IFN- $\alpha$ was the mainstay of mRCC treatment. However, benefit was only marginal considering the toxicities related to therapy. Over the past decade, significant progress has been made in the development of new immunotherapeutic agents in the form of checkpoint inhibition and vaccines, and these agents are gradually being incorporated in the treatment of mRCC and many other cancers, such as melanoma, non-small cell lung cancer, Hodgkin's disease, and head and neck cancer. In mRCC, various checkpoint inhibitors are currently being investigated for use as a first-line agent, following recent USFDA approval of nivolumab in the second-line setting. As the use of immunotherapy becomes more widespread in oncology, many questions will certainly need to be addressed. For example, the long-term side effects and resistance mechanisms of these drugs in various tumors are important considerations. Optimizing treatment dose and schedule, investigating biomarkers that may affect disease outcomes, and evaluating the combination of different treatment modalities are also critical in maximizing the potential of immunotherapy [67]. Further research and experience in this field will allow us to better identify strategies in utilizing immunotherapeutic agents not just in RCC, but also in many other malignancies.

It is now quite clear that immunotherapy is here to stay and has begun to impact the clinical outcome of patients with mRCC. Further enhancements to this efficacy paradigm can be achieved with the use of combination therapies, including with other checkpoint inhibitors and with anti-VEGF TKI. As alluded to earlier in this review, there is strong pre-clinical rationale for combining immunotherapy with anti-VEGF inhibitors. The latter, in particular, have been shown to reduce myeloid derived stem cells (MDSC) that are crucial in tumor-induced immune suppression. Furthermore, development and clinical implementation of predictive biomarkers will be crucial to the use of immunotherapy. Preliminary research, especially the expression of PD-L1 by IHC in the tumor cells, has so far not lived up to the promise of a predictive biomarker [58]. One of the criticisms has been that the tumor samples that are being evaluated are derived from primary site and in the treatment naive setting, which are bound to be immunologically different from cancer samples that have already been exposed to prior therapies. Furthermore, while the knowledge derived from the Cancer Genome Atlas (TCGA) effort is likely to provide a lot more insight into the biology of the tumors, it underperforms on the immunotherapy front, since the major host immune response lies in the stromal cells, which was not part of the TCGA evaluation. Other potential biomarkers include the preexistence of $\mathrm{CD} 8+$ tumor infiltrating lymphocytes (TIL), though these have been directly associated with anti PD-1 therapy only in melanoma and MSI high colorectal cancer [118, 119]. This needs to be explored further in renal cancer.

In this review, we have sought to highlight the entire field of clinical development of immune based therapy for $\mathrm{mRCC}$, and hope that the reader will find this piece of work useful as a summary and as a source of reference. We also recognize that it is a highly dynamic and evolving field, and the pace of development is astounding and encouraging. The use of immune based therapy for this disease, while decades old (in the form of INF and IL-2), offers new promise with the targeting of the checkpoint pathways. The latter field is still in its infancy stage, with tremendous potential for the future. We believe that a major paradigm shift in RCC management will only occur once we can increase the cure rates of surgically managed patients by finding a drug that will improve survival rates in the adjuvant setting. Such trials using TKI and anti PD-1/PD-L1 agents are in progress, and the results are eagerly awaited.

\section{CONFLICTS OF INTERESTS}

The authors declare that they have no competing interests.

\section{Authors' contributions}

K.G. Liu drafted, wrote, edited and reviewed the manuscript. S. Gupta wrote and edited the manuscript. S. Goel drafted, edited and reviewed the manuscript.

\section{REFERENCES}

1. Cairns P. Renal Cell Carcinoma. Cancer Biomarkers. 2011; 9(1-6):461-473.

2. Kirkwood JM, Butterfield LH, Tarhini AA, Zarour H, Kalinski P and Ferrone S. Immunotherapy of cancer in 2012. CA Cancer J Clin. 2012; 62(5):309-335.

3. Rini BI, Campbell SC and Escudier B. Renal cell carcinoma. Lancet (London, England). 2009; 373(9669):1119-1132.

4. Srigley JR, Delahunt B, Eble JN, Egevad L, Epstein JI, 
Grignon D, Hes O, Moch H, Montironi R, Tickoo SK, Zhou $\mathrm{M}$ and Argani P. The International Society of Urological Pathology (ISUP) Vancouver Classification of Renal Neoplasia. The American journal of surgical pathology. 2013; 37(10):1469-1489.

5. Siemer S, Hack M, Lehmann J, Becker F and Stockle M. Outcome of renal tumors in young adults. The Journal of urology. 2006; 175(4):1240-1243; discussion 1243-1244.

6. Thompson RH, Ordonez MA, Iasonos A, Secin FP, Guillonneau B, Russo P and Touijer K. Renal cell carcinoma in young and old patients - is there a difference? The Journal of urology. 2008; 180(4):1262-1266; discussion 1266.

7. Cancer Incidence in Five Continents, Vol. X (electronic version): Lyon: International Agency for Research on Cancer). 2013.

8. Mandel JS, McLaughlin JK, Schlehofer B, Mellemgaard A, Helmert U, Lindblad P, McCredie M and Adami HO. International renal-cell cancer study. IV. Occupation. International journal of cancer Journal international du cancer. 1995; 61(5):601-605.

9. Cho E, Curhan G, Hankinson SE, Kantoff P, Atkins MB, Stampfer M and Choueiri TK. Prospective evaluation of analgesic use and risk of renal cell cancer. Archives of internal medicine. 2011; 171(16):1487-1493.

10. SEER Cancer Statistics Review 1975-2012: Table 11.8 Cancer of the Kidney and Renal Pelvis (Invasive). (National Cancer Institute. Bethesda, Maryland.

11. Zisman A, Pantuck AJ, Dorey F, Said JW, Shvarts O, Quintana D, Gitlitz BJ, deKernion JB, Figlin RA and Belldegrun AS. Improved prognostication of renal cell carcinoma using an integrated staging system. Journal of clinical oncology. 2001; 19(6):1649-1657.

12. Zisman A, Pantuck AJ, Wieder J, Chao DH, Dorey F, Said JW, deKernion JB, Figlin RA and Belldegrun AS. Risk group assessment and clinical outcome algorithm to predict the natural history of patients with surgically resected renal cell carcinoma. Journal of clinical oncology. 2002; 20(23):4559-4566.

13. Motzer RJ, Bacik J, Murphy BA, Russo P and Mazumdar $\mathrm{M}$. Interferon-alfa as a comparative treatment for clinical trials of new therapies against advanced renal cell carcinoma. Journal of clinical oncology. 2002; 20(1):289296.

14. Heng DY, Xie W, Regan MM, Warren MA, Golshayan AR, Sahi C, Eigl BJ, Ruether JD, Cheng T, North S, Venner $\mathrm{P}$, Knox JJ, Chi KN, et al. Prognostic factors for overall survival in patients with metastatic renal cell carcinoma treated with vascular endothelial growth factor-targeted agents: results from a large, multicenter study. Journal of clinical oncology. 2009; 27(34):5794-5799.

15. Motzer RJ, Hutson TE, Tomczak P, Michaelson MD, Bukowski RM, Rixe O, Oudard S, Negrier S, Szczylik C, Kim ST, Chen I, Bycott PW, Baum CM and Figlin RA.
Sunitinib versus interferon alfa in metastatic renal-cell carcinoma. The New England journal of medicine. 2007; 356(2):115-124.

16. Motzer RJ, Hutson TE, Tomczak P, Michaelson MD, Bukowski RM, Oudard S, Negrier S, Szczylik C, Pili R, Bjarnason GA, Garcia-del-Muro X, Sosman JA, Solska E, et al. Overall survival and updated results for sunitinib compared with interferon alfa in patients with metastatic renal cell carcinoma. Journal of clinical oncology. 2009; 27(22):3584-3590.

17. Sternberg CN, Davis ID, Mardiak J, Szczylik C, Lee E, Wagstaff J, Barrios CH, Salman P, Gladkov OA, Kavina A, Zarba JJ, Chen M, McCann L, et al. Pazopanib in locally advanced or metastatic renal cell carcinoma: results of a randomized phase III trial. Journal of clinical oncology. 2010; 28(6):1061-1068.

18. Sternberg CN, Hawkins RE, Wagstaff J, Salman P, Mardiak J, Barrios CH, Zarba JJ, Gladkov OA, Lee E, Szczylik C, McCann L, Rubin SD, Chen M, et al. A randomised, double-blind phase III study of pazopanib in patients with advanced and/or metastatic renal cell carcinoma: final overall survival results and safety update. European journal of cancer (Oxford, England : 1990). 2013; 49(6):1287-1296.

19. Motzer RJ, Hutson TE, Cella D, Reeves J, Hawkins R, Guo J, Nathan P, Staehler M, de Souza P, Merchan JR, Boleti E, Fife K, Jin J, Jones R, Uemura H, De Giorgi U, et al. Pazopanib versus sunitinib in metastatic renal-cell carcinoma. The New England journal of medicine. 2013; 369(8):722-731.

20. Motzer RJ, Hutson TE, McCann L, Deen K and Choueiri TK. Overall survival in renal-cell carcinoma with pazopanib versus sunitinib. The New England journal of medicine. 2014; 370(18):1769-1770.

21. Hudes G, Carducci M, Tomczak P, Dutcher J, Figlin R, Kapoor A, Staroslawska E, Sosman J, McDermott D, Bodrogi I, Kovacevic Z, Lesovoy V, Schmidt-Wolf IG, Barbarash O, Gokmen E, O'Toole T, et al. Temsirolimus, interferon alfa, or both for advanced renal-cell carcinoma. The New England journal of medicine. 2007; 356(22):22712281.

22. Escudier B, Pluzanska A, Koralewski P, Ravaud A, Bracarda S, Szczylik C, Chevreau C, Filipek M, Melichar B, Bajetta E, Gorbunova V, Bay JO, Bodrogi I, et al. Bevacizumab plus interferon alfa-2a for treatment of metastatic renal cell carcinoma: a randomised, doubleblind phase III trial. Lancet (London, England). 2007; 370(9605):2103-2111.

23. Rini BI, Halabi S, Rosenberg JE, Stadler WM, Vaena DA, Archer L, Atkins JN, Picus J, Czaykowski P, Dutcher J and Small EJ. Phase III trial of bevacizumab plus interferon alfa versus interferon alfa monotherapy in patients with metastatic renal cell carcinoma: final results of CALGB 90206. Journal of clinical oncology. 2010; 28(13):21372143. 
24. Escudier B, Szczylik C, Hutson TE, Demkow T, Staehler M, Rolland F, Negrier S, Laferriere N, Scheuring UJ, Cella $\mathrm{D}$, Shah S and Bukowski RM. Randomized phase II trial of first-line treatment with sorafenib versus interferon Alfa-2a in patients with metastatic renal cell carcinoma. Journal of clinical oncology. 2009; 27(8):1280-1289.

25. Hutson TE, Lesovoy V, Al-Shukri S, Stus VP, Lipatov ON, Bair AH, Rosbrook B, Chen C, Kim S and Vogelzang NJ. Axitinib versus sorafenib as first-line therapy in patients with metastatic renal-cell carcinoma: a randomised open-label phase 3 trial. The Lancet Oncology. 2013; 14(13):1287-1294.

26. Choueiri TK, Escudier B, Powles T, Mainwaring PN, Rini BI, Donskov F, Hammers H, Hutson TE, Lee JL, Peltola K, Roth BJ, Bjarnason GA, Geczi L, Keam B, Maroto P, Heng DY, et al. Cabozantinib versus Everolimus in Advanced Renal-Cell Carcinoma. The New England journal of medicine. 2015; 373(19):1814-1823.

27. Choueiri TK, Escudier B, Powles T, Tannir NM, Mainwaring PN, Rini BI, Hammers HJ, Donskov F, Roth BJ, Peltola K, Lee JL, Heng DY, Schmidinger M, Agarwal $\mathrm{N}$, Sternberg CN, McDermott DF, et al. Cabozantinib versus everolimus in advanced renal cell carcinoma (METEOR): final results from a randomised, open-label, phase 3 trial. The Lancet Oncology. 2016; 17(7):917-927.

28. Rini BI, Escudier B, Tomczak P, Kaprin A, Szczylik C, Hutson TE, Michaelson MD, Gorbunova VA, Gore ME, Rusakov IG, Negrier S, Ou YC, Castellano D, Lim HY, Uemura H, Tarazi J, et al. Comparative effectiveness of axitinib versus sorafenib in advanced renal cell carcinoma (AXIS): a randomised phase 3 trial. Lancet (London, England). 2011; 378(9807):1931-1939.

29. Motzer RJ, Escudier B, Tomczak P, Hutson TE, Michaelson MD, Negrier S, Oudard S, Gore ME, Tarazi J, Hariharan S, Chen C, Rosbrook B, Kim S and Rini BI. Axitinib versus sorafenib as second-line treatment for advanced renal cell carcinoma: overall survival analysis and updated results from a randomised phase 3 trial. The Lancet Oncology. 2013; 14(6):552-562.

30. Motzer RJ, Hutson TE, Glen H, Michaelson MD, Molina A, Eisen T, Jassem J, Zolnierek J, Maroto JP, Mellado B, Melichar B, Tomasek J, Kremer A, Kim HJ, Wood K, Dutcus C, et al. Lenvatinib, everolimus, and the combination in patients with metastatic renal cell carcinoma: a randomised, phase 2, open-label, multicentre trial. The Lancet Oncology. 2015; 16(15):1473-1482.

31. Motzer RJ, Escudier B, Oudard S, Hutson TE, Porta C, Bracarda S, Grunwald V, Thompson JA, Figlin RA, Hollaender N, Kay A and Ravaud A. Phase 3 trial of everolimus for metastatic renal cell carcinoma : final results and analysis of prognostic factors. Cancer. 2010; 116(18):4256-4265.

32. Escudier B, Eisen T, Stadler WM, Szczylik C, Oudard S, Staehler M, Negrier S, Chevreau C, Desai AA, Rolland F, Demkow T, Hutson TE, Gore M, Anderson S, Hofilena
G, Shan M, et al. Sorafenib for treatment of renal cell carcinoma: Final efficacy and safety results of the phase III treatment approaches in renal cancer global evaluation trial. Journal of clinical oncology. 2009; 27(20):3312-3318.

33. Oliver RT, Nethersell AB and Bottomley JM. Unexplained spontaneous regression and alpha-interferon as treatment for metastatic renal carcinoma. British journal of urology. 1989; 63(2):128-131.

34. Elhilali MM, Gleave M, Fradet Y, Davis I, Venner P, Saad F, Klotz L, Moore R, Ernst S and Paton V. Placeboassociated remissions in a multicentre, randomized, doubleblind trial of interferon gamma- $1 \mathrm{~b}$ for the treatment of metastatic renal cell carcinoma. The Canadian Urologic Oncology Group. BJU international. 2000; 86(6):613-618.

35. Rendon RA. New surgical horizons: the role of cytoreductive nephrectomy for metastatic kidney cancer. Canadian Urological Association Journal. 2007; 1(2 Suppl):S62-68.

36. Flanigan RC, Salmon SE, Blumenstein BA, Bearman SI, Roy V, McGrath PC, Caton JR, Jr., Munshi N and Crawford ED. Nephrectomy followed by interferon alfa- $2 b$ compared with interferon alfa-2b alone for metastatic renalcell cancer. The New England journal of medicine. 2001; 345(23):1655-1659.

37. Mickisch GH, Garin A, van Poppel H, de Prijck L and Sylvester R. Radical nephrectomy plus interferon-alfabased immunotherapy compared with interferon alfa alone in metastatic renal-cell carcinoma: a randomised trial. Lancet (London, England). 2001; 358(9286):966-970.

38. Culp SH, Tannir NM, Abel EJ, Margulis V, Tamboli P, Matin SF and Wood CG. Can we better select patients with metastatic renal cell carcinoma for cytoreductive nephrectomy? Cancer. 2010; 116(14):3378-3388.

39. Choueiri TK, Xie W, Kollmannsberger C, North S, Knox JJ, Lampard JG, McDermott DF, Rini BI and Heng DY. The impact of cytoreductive nephrectomy on survival of patients with metastatic renal cell carcinoma receiving vascular endothelial growth factor targeted therapy. The Journal of urology. 2011; 185(1):60-66.

40. ClinicalTrials.gov (NCT00930033). Randomized Phase III Trial Evaluating the Importance of Nephrectomy in Patients Presenting With Metastatic Renal Cell Carcinoma Treated With Sunitinib.

41. Coley WB. The treatment of malignant tumors by repeated inoculations of erysipelas: with a report of ten original cases. Am J Med Sci. 1893; 105(5):487-510.

42. Kienle GS. Fever in Cancer Treatment: Coley's Therapy and Epidemiologic Observations. Global Advances in Health and Medicine. 2012; 1(1):92-100.

43. Wiemann B and Starnes CO. Coley's toxins, tumor necrosis factor and cancer research: a historical perspective. Pharmacology \& therapeutics. 1994; 64(3):529-564.

44. Schwartz RH. A cell culture model for T lymphocyte clonal anergy. Science (New York, NY). 1990; 248(4961):1349- 
1356.

45. Pardoll DM. The blockade of immune checkpoints in cancer immunotherapy. Nature reviews Cancer. 2012; 12(4):252264.

46. Fyfe G, Fisher RI, Rosenberg SA, Sznol M, Parkinson DR and Louie AC. Results of treatment of 255 patients with metastatic renal cell carcinoma who received high-dose recombinant interleukin-2 therapy. Journal of clinical oncology. 1995; 13(3):688-696.

47. Klapper JA, Downey SG, Smith FO, Yang JC, Hughes MS, Kammula US, Sherry RM, Royal RE, Steinberg SM and Rosenberg S. High-dose interleukin-2 for the treatment of metastatic renal cell carcinoma : a retrospective analysis of response and survival in patients treated in the surgery branch at the National Cancer Institute between 1986 and 2006. Cancer. 2008; 113(2):293-301.

48. McDermott DF, Regan MM, Clark JI, Flaherty LE, Weiss GR, Logan TF, Kirkwood JM, Gordon MS, Sosman JA, Ernstoff MS, Tretter CP, Urba WJ, Smith JW, Margolin KA, Mier JW, Gollob JA, et al. Randomized phase III trial of high-dose interleukin-2 versus subcutaneous interleukin-2 and interferon in patients with metastatic renal cell carcinoma. Journal of clinical oncology. 2005; 23(1):133-141.

49. Yang JC, Sherry RM, Steinberg SM, Topalian SL, Schwartzentruber DJ, Hwu P, Seipp CA, Rogers-Freezer L, Morton KE, White DE, Liewehr DJ, Merino MJ and Rosenberg SA. Randomized study of high-dose and lowdose interleukin-2 in patients with metastatic renal cancer. Journal of clinical oncology. 2003; 21(16):3127-3132.

50. Drake CG, Jaffee E and Pardoll DM. Mechanisms of immune evasion by tumors. Advances in immunology. 2006; 90:51-81.

51. Vesely MD, Kershaw MH, Schreiber RD and Smyth MJ. Natural innate and adaptive immunity to cancer. Annual review of immunology. 2011; 29:235-271.

52. Walker LS and Sansom DM. The emerging role of CTLA4 as a cell-extrinsic regulator of $\mathrm{T}$ cell responses. Nature reviews Immunology. 2011; 11(12):852-863.

53. Leach DR, Krummel MF and Allison JP. Enhancement of antitumor immunity by CTLA-4 blockade. Science (New York, NY). 1996; 271(5256):1734-1736.

54. Amarnath S, Mangus CW, Wang JCM, Wei F, He A, Kapoor V, Foley JE, Massey PR, Felizardo TC, Riley JL, Levine BL, June $\mathrm{CH}$, Medin JA and Fowler DH. The PDL1-PD1 Axis Converts Human Th1 Cells Into Regulatory T Cells. Science translational medicine. 2011; 3(111):111ra120.

55. Brahmer JR, Drake CG, Wollner I, Powderly JD, Picus J, Sharfman WH, Stankevich E, Pons A, Salay TM, McMiller TL, Gilson MM, Wang C, Selby M, Taube JM, Anders R, Chen L, et al. Phase I study of single-agent anti-programmed death-1 (MDX-1106) in refractory solid tumors: safety, clinical activity, pharmacodynamics, and immunologic correlates. Journal of clinical oncology. 2010; 28(19):3167-3175.

56. Viteri S, González-Cao M, Barrón F, Riso A and Rosell $\mathrm{R}$. Results of clinical trials with anti-programmed death 1/programmed death ligand 1 inhibitors in lung cancer. Translational Lung Cancer Research. 2015; 4(6):756-762.

57. Grosso JF and Jure-Kunkel MN. CTLA-4 blockade in tumor models: an overview of preclinical and translational research. Cancer immunity. 2013; 13:5.

58. Motzer RJ, Escudier B, McDermott DF, George S, Hammers HJ, Srinivas S, Tykodi SS, Sosman JA, Procopio G, Plimack ER, Castellano D, Choueiri TK, Gurney H, Donskov F, Bono P, Wagstaff J, et al. Nivolumab versus Everolimus in Advanced Renal-Cell Carcinoma. The New England journal of medicine. 2015; 373(19):1803-1813.

59. Chen DS and Mellman I. Oncology meets immunology: the cancer-immunity cycle. Immunity. 2013; 39(1):1-10.

60. Wolchok JD, Kluger H, Callahan MK, Postow MA, Rizvi NA, Lesokhin AM, Segal NH, Ariyan CE, Gordon RA, Reed K, Burke MM, Caldwell A, Kronenberg SA, Agunwamba BU, Zhang X, Lowy I, et al. Nivolumab plus ipilimumab in advanced melanoma. The New England journal of medicine. 2013; 369(2):122-133.

61. Motz GT. Deciphering and Reversing Tumor Immune Suppression. 2013; 39(1):61-73.

62. Voron T, Colussi O, Marcheteau E, Pernot S, Nizard M, Pointet AL, Latreche S, Bergaya S, Benhamouda N, Tanchot C, Stockmann C, Combe P, Berger A, Zinzindohoue F, Yagita H, Tartour E, et al. VEGF-A modulates expression of inhibitory checkpoints on CD8(+) $\mathrm{T}$ cells in tumors. The Journal of Experimental Medicine. 2015; 212(2):139-148.

63. Gunturi A and McDermott DF. Potential of new therapies like anti-PD1 in kidney cancer. Current treatment options in oncology. 2014; 15(1):137-146.

64. Rizvi NA, Hellmann MD, Snyder A, Kvistborg P, Makarov V, Havel JJ, Lee W, Yuan J, Wong P, Ho TS, Miller ML, Rekhtman N, Moreira AL, Ibrahim F, Bruggeman C, Gasmi B, et al. Cancer immunology. Mutational landscape determines sensitivity to PD-1 blockade in nonsmall cell lung cancer. Science (New York, NY). 2015; 348(6230):124-128.

65. Sui X, Ma J, Han W, Wang X, Fang Y, Li D, Pan H and Zhang L. The anticancer immune response of anti-PD-1/ PD-L1 and the genetic determinants of response to antiPD-1/PD-L1 antibodies in cancer patients. Oncotarget. 2015; 6:19393-19404. doi:10.18632/oncotarget.5107.

66. Peng D, Kryczek I, Nagarsheth N, Zhao L, Wei S, Wang W, Sun Y, Zhao E, Vatan L, Szeliga W, Kotarski J, Tarkowski R, Dou Y, Cho K, Hensley-Alford S, Munkarah A, et al. Epigenetic silencing of TH1-type chemokines shapes tumour immunity and immunotherapy. Nature. 2015; 527(7577):249-253.

67. Postow MA. Managing immune checkpoint-blocking 
antibody side effects. American Society of Clinical Oncology educational book / ASCO American Society of Clinical Oncology Meeting. 2015:76-83.

68. Younes A, Santoro A, Shipp M, Zinzani PL, Timmerman JM, Ansell S, Armand P, Fanale M, Ratanatharathorn V, Kuruvilla J, Cohen JB, Collins G, Savage KJ, Trneny M, Kato K, Farsaci B, et al. Nivolumab for classical Hodgkin's lymphoma after failure of both autologous stem-cell transplantation and brentuximab vedotin: a multicentre, multicohort, single-arm phase 2 trial. The Lancet Oncology. 2016.

69. Opdivo ${ }^{\circledR}$ [package insert]. Bristol-Myers Squibb Company, Princeton, NJ. http://packageinserts.bms.com/pi/pi_opdivo. pdf. Accessed: Nov 24, 2016.

70. Motzer RJ, Rini BI, McDermott DF, Redman BG, Kuzel TM, Harrison MR, Vaishampayan UN, Drabkin HA, George S, Logan TF, Margolin KA, Plimack ER, Lambert AM, Waxman IM and Hammers HJ. Nivolumab for Metastatic Renal Cell Carcinoma: Results of a Randomized Phase II Trial. Journal of clinical oncology. 2015; 33(13):1430-1437.

71. ClinicalTrials.gov (NCT02446860). A Study of Anti-PD1 (Nivolumab) Therapy as Pre- and Post-operative Therapy in Metastatic Renal Cell Cancer (ADAPTeR).

72. ClinicalTrials.gov (NCT01472081). A Phase 1 Study of Nivolumab (BMS-936558) Plus Sunitinib, Pazopanib or Ipilimumab in Subjects With Metastatic Renal Cell Carcinoma.

73. ClinicalTrials.gov (NCT02231749). A Phase 3, Randomized, Open-Label Study of Nivolumab Combined With Ipilimumab Versus Sunitinib Monotherapy in Subjects With Previously Untreated, Advanced or Metastatic Renal Cell Carcinoma.

74. ClinicalTrials.gov (NCT02210117). A Pilot Randomized Tissue-Based Study Evaluating Anti-PD1 Antibody or Anti-PD1 + Bevacizumab or Anti-PD1 + Anti-CTLA-4 in Patients With Metastatic Renal Cell Carcinoma Who Are Eligible for Cytoreductive Nephrectomy, Metastasectomy or Post-Treatment Biopsy.

75. ClinicalTrials.gov (NCT02335918). A Phase 1/11 Dose Escalation and Cohort Expansion Study of the Safety, Tolerability and Efficacy of Anti-CD27 Antibody (Varlilumab) Administered in Combination With Anti-PD-1 (Nivolumab) in Advanced Refractory Solid Tumors.

76. ClinicalTrials.gov (NCT02614456). Combination Immunotherapy With Interferon-gamma and Nivolumab for Patients With Advanced Solid Tumors: A Phase 1 Study.

77. Larkin J, Chiarion-Sileni V, Gonzalez R, Grob JJ, Cowey CL, Lao CD, Schadendorf D, Dummer R, Smylie M, Rutkowski P, Ferrucci PF, Hill A, Wagstaff J, Carlino MS, Haanen JB, Maio M, et al. Combined Nivolumab and Ipilimumab or Monotherapy in Untreated Melanoma. The New England journal of medicine. 2015; 373(1):23-34.

78. Hammers HJ, Plimack ER, Infante JR, Ernstoff MS, Rini
BI, McDermott DF, Razak ARA, Pal SK, Voss MH, Sharma P, Kollmannsberger C, Heng DYC, Spratlin JL, Shen Y, Kurland JF, Gagnier P, et al. Phase I study of nivolumab in combination with ipilimumab in metastatic renal cell carcinoma (mRCC). Journal of clinical oncology. 2014; 32(5_suppl:abstr \#4504).

79. ClinicalTrials.gov (NCT00057889). A Phase II Open-Label Study of Single Agent MDX-010 for the Treatment of IL-2 Refractory or IL-2 Ineligible Patients With Stage IV Renal Cancer.

80. ClinicalTrials.gov (NCT02381314). A Phase 1, OpenLabel, Dose Escalation Study of MGA271 in Combination With Ipilimumab in Patients With B7-H3-Expressing Melanoma, Squamous Cell Cancer of the Head and Neck, Non Small Cell Lung Cancer, and Other B7H3 Expressing Cancers.

81. Keytruda ${ }^{\circledR}$ [package insert]. Merck \& Co., Inc., Whitehouse Station, NJ. http://www.merck.com/product/usa/pi circulars/k/keytruda/keytruda_pi.pdf. Accessed: Nov 24, 2016.

82. Atkins MB, Choueiri TK, Hodi FS, Thompson JA, Hwu W, McDermott DF, Brookes M, Tosolini A, Ebbinghaus S, Yang Z, Gause CK, Perini RF and Ribas A. Pembrolizumab (MK-3475) plus low-dose ipilimumab (IPI) in patients (pts) with advanced melanoma (MEL) or renal cell carcinoma (RCC): Data from the KEYNOTE-029 phase 1 study. Journal of clinical oncology. 2015; 33(suppl:abstr \#3009).

83. ClinicalTrials.gov (NCT02014636). A Phase I/II Study to Assess the Safety and Efficacy of Pazopanib and MK 3475 in Subjects With Advanced Renal Cell Carcinoma.

84. ClinicalTrials.gov (NCT02133742). A Phase 1b, Open Label, Dose Finding Study To Evaluate Safety, Pharmacokinetics And Pharmacodynamics Of Axitinib (AG-013736) In Combination With Pembrolizumab (MK3475) In Patients With Advanced Renal Cell Cancer.

85. ClinicalTrials.gov (NCT02348008). Phase Ib and Phase II Studies of Anti-PD-1 Antibody MK-3475 in Combination With Bevacizumab for the Treatment of Metastatic Renal Cell Carcinoma: Big Ten Cancer Research Consortium GU14-003.

86. ClinicalTrials.gov (NCT02089685). A Phase I/II Clinical Trial to Study the Safety and Tolerability of MK-3475 + Pegylated Interferon Alfa-2b (PEG-IFN) and MK-3475 + Ipilimumab (IPI) in Subjects With Advanced Melanoma (MEL) and Renal Cell Carcinoma (RCC) (KEYNOTE 029).

87. ClinicalTrials.gov (NCT02501096). A Multicenter, Open-Label Phase 1b/2 Trial of Lenvatinib (E7080) Plus Pembrolizumab in Subjects With Selected Solid Tumors.

88. ClinicalTrials.gov (NCT02619253). A Phase I/Ib, Open Label, Dose Finding Study to Evaluate Safety, Pharmacodynamics and Efficacy of Pembrolizumab (MK3475) in Combination With Vorinostat in Patients With Advanced Renal or Urothelial Cell Carcinoma.

89. ClinicalTrials.gov (NCT02298959). A Phase 1 Trial of MK- 
3475 Plus Ziv-Aflibercept in Patients With Advanced Solid Tumors.

90. ClinicalTrials.gov (NCT02646748). A Platform Study Exploring the Safety, Tolerability, Effect on the Tumor Microenvironment, and Efficacy of Pembrolizumab + INCB Combinations in Advanced Solid Tumors.

91. ClinicalTrials.gov (NCT02178722). A Phase 1/2 Study Exploring the Safety, Tolerability, and Efficacy of Pembrolizumab (MK-3475) in Combination With Epacadostat (INCB024360) in Subjects With Selected Cancers (KEYNOTE-037/ ECHO-202).

92. ClinicalTrials.gov (NCT02475213). A Phase 1, OpenLabel, Dose Escalation Study of MGA271 in Combination With Pembrolizumab in Patients With B7-H3-Expressing Melanoma, Squamous Cell Cancer of the Head and Neck, Non-Small Cell Lung Cancer and Other B7H3 Expressing Cancers.

93. McDermott DF, Sosman JA, Sznol M, Massard C, Gordon MS, Hamid O, Powderly JD, Infante JR, Fasso M, Wang YV, Zou W, Hegde PS, Fine GD and Powles T. Atezolizumab, an Anti-Programmed Death-Ligand 1 Antibody, in Metastatic Renal Cell Carcinoma: LongTerm Safety, Clinical Activity, and Immune Correlates From a Phase Ia Study. Journal of clinical oncology. 2016; 34(8):833-842.

94. ClinicalTrials.gov (NCT01984242). A Phase II, Randomized Study of Atezolizumab Administered as Monotherapy or In Combination With Bevacizumab Versus Sunitinib In Patients With Untreated Advanced Renal Cell Carcinoma.

95. ClinicalTrials.gov (NCT02420821). A Phase III, OpenLabel, Randomized Study Of Atezolizumab (Anti-PD-L1 Antibody) in Combination With Bevacizumab Versus Sunitinib in Patients With Untreated Advanced Renal Cell Carcinoma.

96. ClinicalTrials.gov (NCT02543645). A Phase 1/11, Open Label, Dose-escalation Study of Varlilumab (CDX-1127) in Combination With Atezolizumab (MPDL3280A, AntiPD-L1) in Patients With Advanced Cancer.

97. ClinicalTrials.gov (NCT02655822). A Phase 1/1b, OpenLabel, Multicenter, Repeat-Dose, Dose-Selection Study of CPI-444 as Single Agent and in Combination With Atezolizumab in Patients With Selected Incurable Cancers.

98. Kelly K, Patel MR, Infante JR, Iannoti N, Nikolinakos P, Leach J, Wang D, Chandler JC, Heinrich G, Jerusalem M, Gurtler JS, Arkenau H, Speit I, von Heydebreck A, Chin KM, Heery CR, et al. Avelumab (MSB0010718C), an anti-PD-L1 antibody, in patients with metastatic or locally advanced solid tumors: assessment of safety and tolerability in a phase I, open-label expansion study. Journal of clinical oncology. 2015; 33(suppl:abstr \#3044).

99. ClinicalTrials.gov (NCT02493751). A Phase 1b, Open-Label, Dose-Finding Study To Evaluate Safety, Pharmacokinetics And Pharmacodynamics Of Avelumab (MSB0010718C) In Combination With Axitinib (AG-
013736) In Patients With Previously Untreated Advanced Renal Cell Cancer.

100. ClinicalTrials.gov (NCT02684006). A Phase 3, Multinational, Randomized, Open-Label, Parallel-Arm Study Of Avelumab (MSB0010718C) In Combination With Axitinib (Inlyta(Registered)) Versus Sunitinib (Sutent(Registered)) Monotherapy In The First-Line Treatment Of Patients With Advanced Renal Cell Carcinoma.

101. Rizvi NA, Brahmer JR, Ou SI, Segal NH, Khleif S, Hwu W, Gutierrez M, Schoffski P, Hamid O, Weiss J, Lutzky J, Maio M, Nemunaitis JJ, Jaeger D, Balmanoukian AS, Rebelatto $\mathrm{M}$, et al. Safety and clinical activity of MEDI4736, an anti-programmed cell death-ligand 1 (PD-L1) antibody, in patients with non-small cell lung cancer (NSCLC). Journal of clinical oncology. 2015; 33(supp:abstr\# 8032).

102. ClinicalTrials.gov (NCT01975831). A Phase 1 Study to Evaluate the Safety and Tolerability of Anti-PD-L1, MEDI4736, in Combination With Tremelimumab in Subjects With Advanced Solid Tumors.

103. ClinicalTrials.gov (NCT02118337). A Phase 1/2, Openlabel Study to Evaluate the Safety and Antitumor Activity of MEDI0680 (AMP-514) in Combination With MEDI4736 and MEDI0680 Monotherapy in Subjects With Select Advanced Malignancies.

104. Yervoy ${ }^{\circledR}$ [package insert]. Bristol-Myers Squibb Company P, NJ. http://packageinserts.bms.com/pi/pi_yervoy.pdf. Accessed: Nov 24, 2016.

105. Amin A, Dudek A, Logan T, Lance RS, Holzbeierlein JM, Williams WL, Jain R, Chew TG, Nicolette CA and Figlin RA. A phase II study testing the safety and activity of AGS-003 as an immunotherapeutic in subjects with newly diagnosed advanced stage renal cell carcinoma (RCC) in combination with sunitinib. Journal of clinical oncology. 2010; 28(15_suppl: abstr \#4588).

106. ClinicalTrials.gov (NCT01582672). An International Phase 3 Randomized Trial of Autologous Dendritic Cell Immunotherapy (AGS-003) Plus Standard Treatment of Advanced Renal Cell Carcinoma (ADAPT).

107. Walter S, Weinschenk T, Stenzl A, Zdrojowy R, Pluzanska A, Szczylik C, Staehler M, Brugger W, Dietrich PY, Mendrzyk R, Hilf N, Schoor O, Fritsche J, Mahr A, Maurer D, Vass V, et al. Multipeptide immune response to cancer vaccine IMA901 after single-dose cyclophosphamide associates with longer patient survival. Nature medicine. 2012; 18(8):1254-1261.

108. Rini B, Stenzl A and Zdrojowy R. Results from an openlabel, randomized, controlled phase 3 study investigating IMA901 multipeptide cancer vaccine in patients receiving sunitinib as first-line therapy for advanced/metastatic RCC. Presented at: 2015 European Cancer Congress. 2015; (Abstr \# LBA 17).

109. Griffiths RW, Gilham DE, Dangoor A, Ramani V, Clarke NW, Stern PL and Hawkins RE. Expression of the 5T4 oncofoetal antigen in renal cell carcinoma: a potential target 
for T-cell-based immunotherapy. British journal of cancer. 2005; 93(6):670-677.

110. Amato RJ, Hawkins RE, Kaufman HL, Thompson JA, Tomczak P, Szczylik C, McDonald M, Eastty S, Shingler WH, de Belin J, Goonewardena M, Naylor S and Harrop R. Vaccination of metastatic renal cancer patients with MVA5T4: a randomized, double-blind, placebo-controlled phase III study. Clinical cancer research. 2010; 16(22):5539-5547.

111. ClinicalTrials.gov (NCT01826877). A Phase I, Open Label, Dose Escalation and Cohort Expansion Study to Evaluate the Safety and Immune Response to Autologous Dendritic Cells Transduced With Ad-GMCAIX in Patients With Metastatic Renal Cell Carcinoma.

112. ClinicalTrials.gov (NCT01441765). Phase II Study of PD-1 Blockade Alone or In Conjunction With the Dendritic Cell (DC)/Renal Cell Carcinoma (RCC) Fusion Cell Vaccination.

113. ClinicalTrials.gov (NCT00862303). Study of Autologous Dendritic Cells (DC) Loaded With Autologous Tumor Lysate (DC-Vaccine) in Combination With CytokineInduced Killer Cell (CIK) in Patients With Renal Cell Cancer.

114. Smaldone MC, Fung C, Uzzo RG and Haas NB. Adjuvant and neoadjuvant therapies in high-risk renal cell carcinoma. Hematology/oncology clinics of North America. 2011; 25(4):765-791.
115. Chakrabarty A, Hillman GG, Maughan RL, Ali E, Pontes JE and Haas GP. Radiation therapy enhances the therapeutic effect of immunotherapy on pulmonary metastases in a murine renal adenocarcinoma model. In vivo (Athens, Greece). 1994; 8(1):25-31.

116. De Meerleer G, Khoo V, Escudier B, Joniau S, Bossi A, Ost P, Briganti A, Fonteyne V, Van Vulpen M, Lumen N, Spahn M and Mareel M. Radiotherapy for renal-cell carcinoma. The Lancet Oncology. 2014; 15(4):e170-177.

117. ClinicalTrials.gov (NCT02318771). An Exploratory Study to Investigate the Immunomodulatory Activity of Radiation Therapy (RT) in Combination With MK-3475 in Patients With Recurrent/Metastatic Head and Neck, Renal Cell Cancer, Melanoma and Lung Cancer.

118. Tumeh PC, Harview CL, Yearley JH, Shintaku IP, Taylor EJ, Robert L, Chmielowski B, Spasic M, Henry G, Ciobanu V, West AN, Carmona M, Kivork C, Seja E, Cherry G, Gutierrez AJ, et al. PD-1 blockade induces responses by inhibiting adaptive immune resistance. Nature. 2014; 515(7528):568-571.

119. Le DT, Uram JN, Wang H, Bartlett BR, Kemberling $\mathrm{H}$, Eyring AD, Skora AD, Luber BS, Azad NS, Laheru D, Biedrzycki B, Donehower RC, Zaheer A, Fisher GA, Crocenzi TS, Lee JJ, et al. PD-1 Blockade in Tumors with Mismatch-Repair Deficiency. The New England journal of medicine. 2015; 372(26):2509-2520. 